\title{
Determination of the Fish Community Structure of an Intertidal Rocky Zone of the Pacific Coast of Baja California Sur
}

\author{
Laura E. Cota-Ortega ${ }^{1}$, Emelio Barjau-Gonzalez ${ }^{1 *}{ }^{\circledR}$, Juan Manuel López-Vivas ${ }^{1}$ (i),

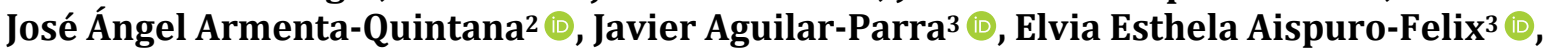 \\ Abril Karim Romo Piñera1 (1)
}

\footnotetext{
${ }^{1}$ Departamento Académico de Ciencias Marinas y Costeras, Universidad Autónoma de Baja California Sur, La Paz, B.C.S. ${ }^{2}$ Departamento Académico de Ciencia Animal y Conservación del Hábitat, Universidad Autónoma de Baja California Sur, La Paz, B.C.S. ${ }^{3}$ Departamento Académico de Sistemas Computacionales, Universidad Autónoma de Baja California Sur, La Paz, B.C.S. Email: *ebarjau@uabcs.mx, lcotaortega9@gmail.com,jmlopez@uabcs.mx,jarmenta@uabcs.mx, jaguilar@uabcs.mx, aispuro@uabcs.mx, akromo@uabcs.mx
}

How to cite this paper: Cota-Ortega, L.E., Barjau-Gonzalez, E., López-Vivas, J.M., Armenta-Quintana, J.Á., Aguilar-Parra, J., Aispuro-Felix, E.E. and Piñera, A.K.R. (2022) Determination of the Fish Community Structure of an Intertidal Rocky Zone of the Pacific Coast of Baja California Sur. Open Journal of Marine Science, 12, 1-18. https://doi.org/10.4236/ojms.2022.121001

Received: October 29, 2021

Accepted: December 28, 2021

Published: January 1, 2022

Copyright ( 2022 by author(s) and Scientific Research Publishing Inc. This work is licensed under the Creative Commons Attribution International License (CC BY 4.0).

http://creativecommons.org/licenses/by/4.0/

\begin{abstract}
The intertidal zone (also known as seashore) are transition areas between land and sea, that are greatly influenced by the tide cycle, therefore, environmental parameters, such as temperature and salinity, oscillate according to the periods in which these areas are exposed to air. Intertidal zones are highly diverse, which makes them key ecosystems for the development of sea life (both flora and fauna) exposed to drastic environmental change. The 59 visual censuses campaigns were carried out during the full moon of each month from 2015 to 2019. Temperature, salinity and dissolved oxygen were recorded during each visual census and showed variations between years. Temperature showed two distinct seasons, warm and cold. A total of 14,995 organisms were recorded, belonging to 30 species, 28 genera, 15 families, five orders and one class. Ecological indices like species richness (SR), Shannon-Wiener's diversity $\left(\mathrm{H}^{\prime}\right)$ and Fisher's alpha ( $\alpha$-Fisher) showed significant differences between years, 2015 and 2016 recorded as the most diverse years, while the lowest values were recorded in 2019. Therefore, fish communities of tide pools showed to be highly diverse, with 30 species recording similar relative abundances, and according to the BVI, only 11 species were dominant. Spatio-temporal variations of temperature, salinity and dissolved oxygen were highly correlated to changes in fish community structure, and the dominance of certain species, which are of great importance for the structure and dynamic of the tide pool communities. Therefore, the aim of the present study was to determine the fish community structure of tide pools during the low tide in the intertidal zone of a locality known as El Faro, on the west coast of La Paz, B. C. S., Mexico.
\end{abstract}




\section{Keywords}

Rockpools, Ecological Indices, Fish Community Structure, Intertidal Zone

\section{Introduction}

The Pacific coast of the state of Baja California Sur in México, ranges from Cabo San Lucas on the south (tip of the Baja California peninsula) to Guerrero Negro $\left(28^{\text {th }}\right.$ parallel north). During the spring/summer months (April to June), this area is influenced by the California current, which brings cold and nutrient rich water to the surface (also known as an upwelling zone), that when collide with the warm waters from the North equatorial current, form a transition zone between Magdalena Bay and Guadalupe Island known as an ecotone (region of transition between two biological communities), which is a highly productive and diverse area that serves as breeding ground for many fish species, and is inhabited by many species of high commercial value [1] [2]. This coastal area is characterized by an intertidal zone, which is a transition area between land and sea that is composed by a heterogeneous rocky substrate forming tide pools, which are highly diverse bodies of water that serve as permanent or seasonal shelter for many species of fishes and invertebrates [3].

Physicochemical variables like temperature, salinity and dissolved oxygen can drastically fluctuate throughout the day in the intertidal zone, according to the tide cycle, particularly when tide pools are exposed to air and intense solar radiation during the low tide, which increases evaporation of the water trapped in the tide pools, increasing its temperature and salinity. On the contrary, if there is precipitation, freshwater from the rain causes a decrease in salinity of the water trapped in the tide pools. Furthermore, dissolved oxygen tends to decrease during nighttime when photosynthetic activity diminishes and respiration from both producers and consumers increases [4]. Therefore, these environmental variables directly affect the structure and dynamic of the fish community of tide pools, because of their influence on species movement in and out of this area, alongside other biological pressures such as algae overgrowth, algae cover and competition with invertebrates over food resources [3]. Tide pools are commonly used as shelter and feeding ground, particularly for herbivorous fishes, mollusks, echinoderms, which tend to be present in higher abundances. Accordingly, tide pools represent an important source of energy, which is transferred to higher trophic levels, playing a key role in the structure and functioning of these coastal ecosystems [5]. Therefore, the goal of this study is to determine the structure of the fish communities that become trapped in the tide pools during the low tide in the intertidal zone of the locality known as "El Faro" on the Pacific Coast of La Paz, B. C. S. 


\section{Methods}

\section{Study area}

Conquista Agraria is a common land located $70 \mathrm{~km}$ northwest of La Paz, Baja California Sur, between the parallels N23 ${ }^{\circ} 57.351^{\prime}$ and meridians W110 $52.437^{\prime}$. The visual censuses were carried out in an area known as "El Faro", from $\mathrm{N} 23^{\circ} 57.553^{\prime}$ and $\mathrm{W} 110^{\circ} 52.654^{\prime}$ to $\mathrm{N} 23^{\circ} 57.622^{\prime}$ and W110 $52.705^{\prime}$ (Figure 1).

A total of 59 visual censuses campaigns were carried out during the full moon of each month (January-December) from 2015 to 2019. The census from October 2019 was not carried out because of extreme weather conditions during the full moon. All censuses were carried out in the supralittoral zone during the afternoon low tide (13:30-17:30 hrs.) in a transect of $156 \times 5 \mathrm{~m}$ and a total of 145 tide pools, which were classified in three groups according to their size: small (2 $\left.\mathrm{m}^{2}\right)$, medium $\left(4 \mathrm{~m}^{2}\right)$ and large $\left(7 \mathrm{~m}^{2}\right)$, recording 85,48 and 12 tide pools, respectively. Depth of tide pools ranged between 20 and $40 \mathrm{~cm}$. Physicochemical variables (temperature, salinity and dissolved oxygen) were recorded using a YSI 2030 Pro multiparameter instrument. Species identification was carried out using

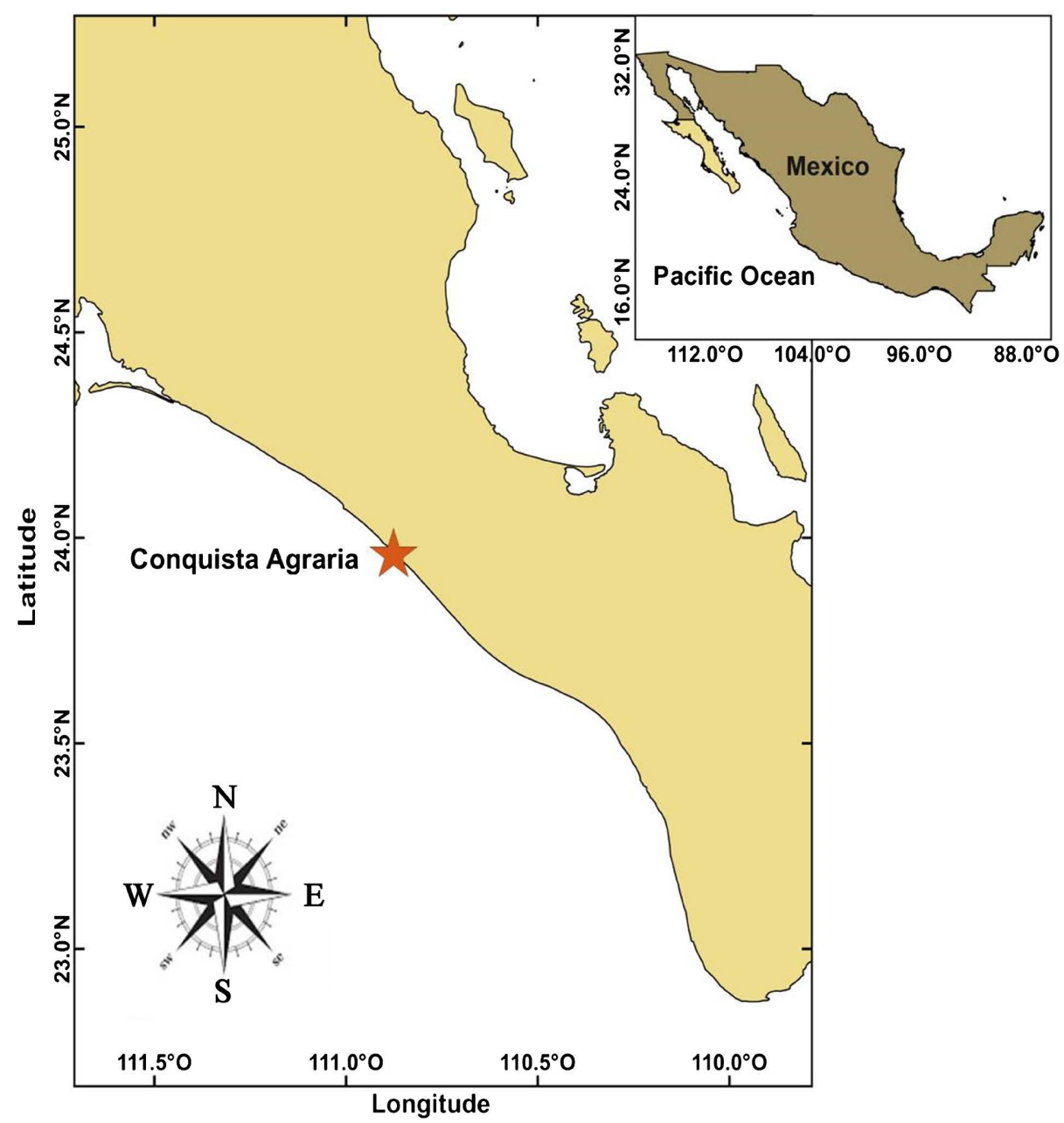

Figure 1. Geographic location of the study area known as "El Faro", located in the common land Conquista Agraria, Baja California Sur. 
specialized literature [6]-[12], and total abundance of species was recorded. Statistical analyses were carried out using the software STATISTICA version 12 . Ecological indices were calculated using the software PRIMER \& PERMANOVA version 7. The following ecological indices were used to describe the fish community structure of tide pools:

Relative abundance: This is an arithmetic expression measured as a percentage to calculate the number of individuals of each species relative to the total abundance of individuals [13]:

$$
R A=n / T N * 100
$$

where: $R A=$ relative abundance, $n=$ number of individuals of each species, $T N$ $=$ total number of individuals.

Diversity. This index describes the diversity of species in a community. In this case, Shannon-Wiener $(H)$ index with logarithm base 2 was used. $H^{\prime}$ units are expressed as bits/individual (bits/ind).

$$
H^{\prime}=-\sum p_{i} \log _{2} p_{i} \quad i=1
$$

where: $H^{\prime}=$ Shannon-Weiner index, $p_{i}=$ proportion of species $i$.

Fisher's alpha ( $\alpha$-Fisher): This index evaluates diversity according to number of individuals and number of species (Condit et al., 1996), and assumes that abundance of species follows a logistic distribution.

$$
S=\alpha \log (1+N / \alpha)
$$

where: $S=$ number of species in the sample, $N=$ number of individuals in the sample, and $\alpha=$ diversity coefficient.

Species richness: This index measures the number of species in a community, and it is usually used as a measure of biodiversity [15]. Margalef s species richness index was used as follow:

$$
D=(S-1) / \ln N
$$

where: $D=$ species richness, $S=$ number of species, $N=$ number of individuals.

Dominance: This index measures the proportion of most abundant species, considering a hierarchy from it, according to frequency of appearance and abundance. The biological value index (BVI) proposed by Sanders (1960), was used to measure dominance as follow:

$$
\text { JB.V.I }=\sum p u_{i j} \quad i=1
$$

where: $p u_{i j}=$ score of species $i$ in the sample $j$.

Classification by relative abundance and frequency of appearance. Species were classified in four groups according to their relative abundance and frequency of appearance, as follow:

1) Abundant: Species with a relative abundance above $1 \%$.

2) Frequent: Species with a relative abundance ranging from $0.10 \%$ to $0.99 \%$.

3) Common: Species with a relative abundance ranging from $0.02 \%$ to $0.09 \%$.

4) Rare: Species with a relative abundance ranging from $0.007 \%$ to $0.01 \%$. 


\section{Results}

\section{Physicochemical variables}

Mean temperature of tide pools showed significant differences between months $(\mathrm{F}(11,47)=7.7905, \mathrm{p}<0.001)$ and years $(\mathrm{F}(4,10)=187.7193, \mathrm{p}<0.001)$, recording the higher values from July to November, with September as the hottest month $\left(31.96^{\circ} \mathrm{C}\right)$, followed by October and August $\left(31.02^{\circ} \mathrm{C}\right.$ and $29.98^{\circ} \mathrm{C}$, respectively). The lower values were recorded from December to June, with January as the coldest month $\left(25.02^{\circ} \mathrm{C}\right)$. Regarding sea temperatures, the warmest values were recorded from August to November. Furthermore, annual sea temperatures showed differences, with 2019 recording the lowest value $\left(25.19^{\circ} \mathrm{C}\right)$, while 2016 recorded the highest value $\left(28.69^{\circ} \mathrm{C}\right)$, followed by $2015\left(28.10^{\circ} \mathrm{C}\right)$ and 2017 and 2018 showing similar values (Table 1).

Salinity of tide pools showed significant differences between months (F (12, $105)=2.2295, \mathrm{p}=0.0151$ ), with the highest values recorded during November and December (33.04 and 34.13 UPS, respectively). Furthermore, annual salinity values showed significant differences $(\mathrm{F}(4,14)=60.64, \mathrm{p}<0.001)$, with 2018

Table 1. Physicochemical variables: T (temperature- $\left.{ }^{\circ} \mathrm{C}\right)$, Sal (Salinity-UPS), DO (Dissolved oxygen-mg/l) and ecological indices: SR (Species richness-D), $\alpha$-Fisher (Fisher's alpha) and SW (Shannon-Wiener index- $\mathrm{H}^{\prime}(\log 10)$ (bits/ind)), recorded in the tide pools of El Faro.

\begin{tabular}{|c|c|c|c|c|c|c|}
\hline Years/Months & $\mathrm{T}\left({ }^{\circ} \mathrm{C}\right)$ & Sal (UPS) & $\mathrm{DO}(\mathrm{mg} / \mathrm{L})$ & $S R(D)$ & $a$-Fisher & SW $\left(\mathrm{H}^{\prime} \log 10\right)$ \\
\hline 2015 & 28.10 & 28.95 & 10.89 & 2.80 & 5.15 & 0.96 \\
\hline 2016 & 28.69 & 30.56 & 7.53 & 2.52 & 4.41 & 0.95 \\
\hline 2017 & 27.63 & 31.66 & 7.52 & 2.09 & 3.49 & 0.85 \\
\hline 2018 & 27.47 & 35.10 & 7.32 & 1.97 & 3.31 & 0.82 \\
\hline 2019 & 25.19 & 34.69 & 8.30 & 1.87 & 3.33 & 0.72 \\
\hline Jan & 25.02 & 31.88 & 9.47 & 1.99 & 3.51 & 0.81 \\
\hline Feb & 26.33 & 32.30 & 7.97 & 2.12 & 3.67 & 0.86 \\
\hline Mar & 26.61 & 32.24 & 7.88 & 2.34 & 4.00 & 0.88 \\
\hline Apr & 26.26 & 31.65 & 8.58 & 2.44 & 4.33 & 0.90 \\
\hline May & 25.49 & 32.61 & 8.31 & 2.34 & 4.21 & 0.85 \\
\hline Jun & 25.25 & 31.82 & 7.15 & 2.49 & 4.45 & 0.89 \\
\hline Jul & 27.24 & 32.00 & 6.70 & 2.59 & 4.51 & 0.93 \\
\hline Aug & 29.98 & 32.89 & 7.42 & 2.33 & 3.98 & 0.91 \\
\hline Sep & 31.96 & 32.58 & 7.23 & 2.20 & 3.80 & 0.86 \\
\hline Oct & 31.02 & 27.80 & 8.94 & 1.71 & 2.86 & 0.68 \\
\hline Nov & 28.88 & 33.04 & 8.06 & 2.34 & 4.17 & 0.88 \\
\hline Dec & 26.07 & 34.13 & 11.56 & 2.11 & 3.76 & 0.85 \\
\hline SEA & 23.95 & 33.61 & 8.23 & - & - & - \\
\hline
\end{tabular}




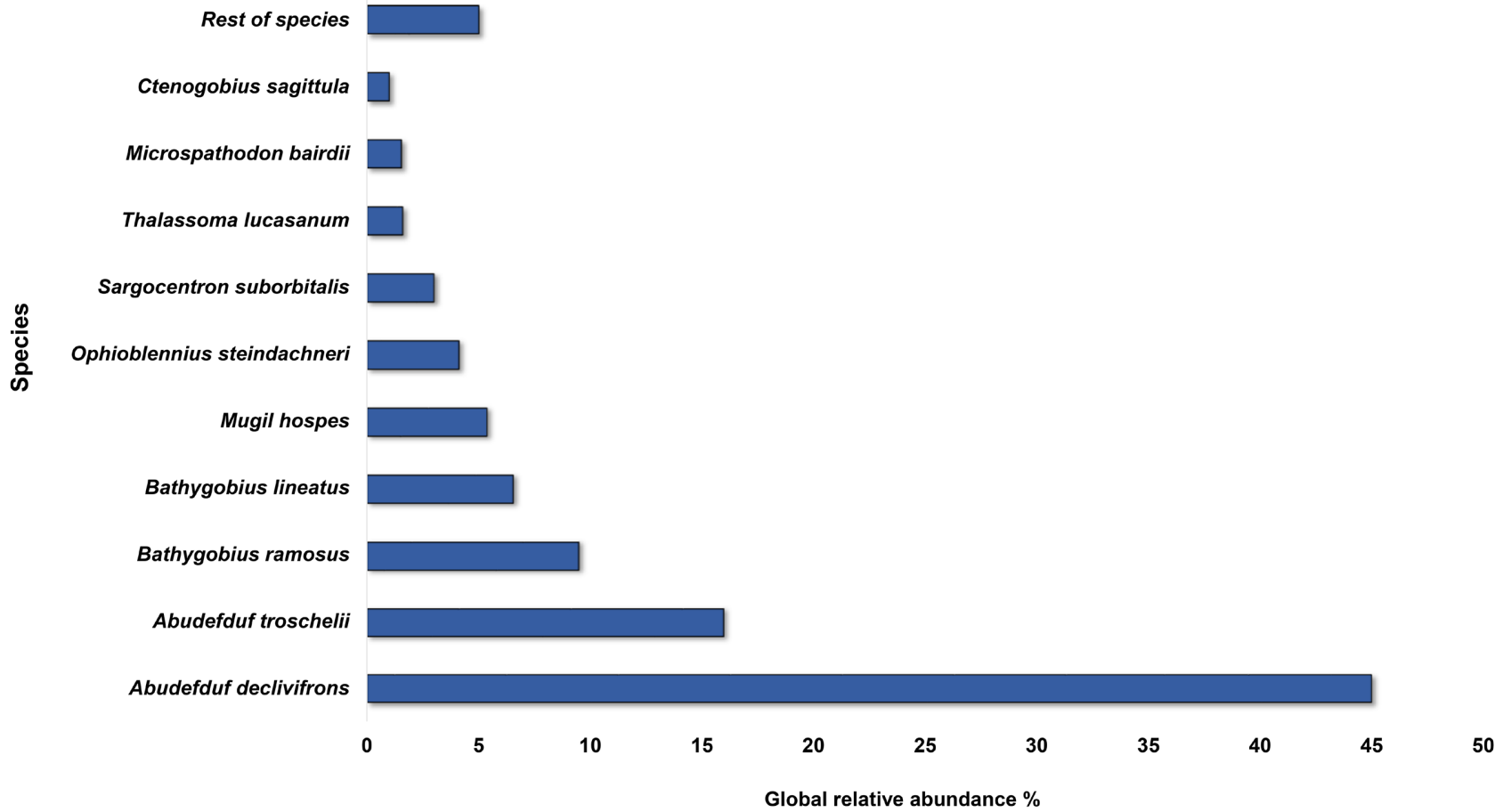

Figure 2. Relative abundance of the fish species recorded in the tide pools of El Faro. 
years $(\mathrm{F}(4,55)=6.2926, \mathrm{p}<0.001)$, with 2015 showing the highest value $\left(\mathrm{H}^{\prime}=\right.$ 0.96 bits/org), followed by 2016 and $2017\left(\mathrm{H}^{\prime}=0.95\right.$ and 0.85 bits/org respectively), and 2019 with the lowest value $\left(\mathrm{H}^{\prime}=0.72\right.$ bits/org) (Figure 3, Table 1). Fisher's alpha ( $\alpha$-Fisher) showed significant differences between years $(\mathrm{F}(4,55)=$ $6.1721, \mathrm{p}<0.001)$, with 2015 showing the highest value $(S=5.15)$, followed by $2016(\mathrm{~S}=4.41)$, while the lowest value was recorded in 2019 ( $\mathrm{S}=3.31$ ) (Figure 4, Table 1). Species richness showed significant differences between years (F (4, $55)=7.0128, \mathrm{p}<0.001)$, with 2015 showing the highest value $(\mathrm{d}=2.80)$, followed by 2016 and 2017 ( $\mathrm{d}=2.52$ y 2.09, respectively), and 2019 with the lowest value $(\mathrm{d}=1.87$ ) (Figure 5 , Table 1$)$. According to the biological value index (BVI), 11 species were recorded as dominant: A. declivifrons, A. troschelii, Bathygobius ramosus, Bathygobius lineatus, Mugil hospes, Ophioblennius steindachneri, Sargocentron suborbitalis, Thalassoma lucasanum, Microsphathodon bairdii, Ctenogibius sagittula and Chriolepis Minutillus (Figure 6).

30 species were classified according to their relative abundance and frequency of appearance as follow (Figure 7):

Abundant species

10 species were classified as abundant, recording a relative abundance above 1\%: A. declivifrons, A. troschelii, B. ramosus, B. lineatus, M. hospes, O. steindachneri, S. suborbitalis, T. lucasanum, M. bairdii and Ctenogobius sagittula.

\section{Frequent species}

10 species were classified as frequent, recording a relative abundance between $0.10 \%$ to $0.99 \%$ : Chriolepis minutillus, Girella nigricans, Labrisomus xanti,

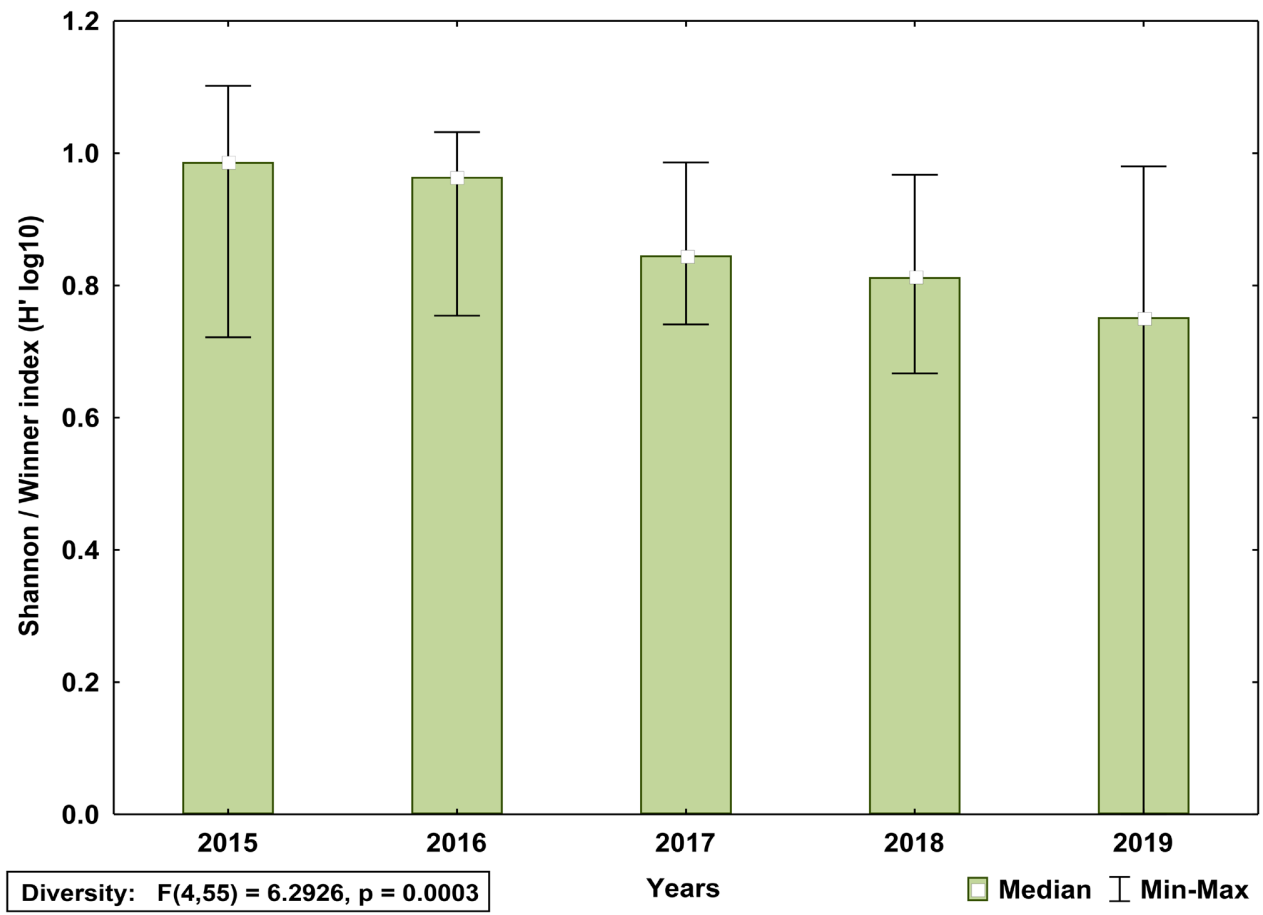

Figure 3. Annual Shannon-Wiener index $\left(\mathrm{H}^{\prime}\right)$ values recorded in the tide pools of El Faro. Confidence interval of $95 \%$. 


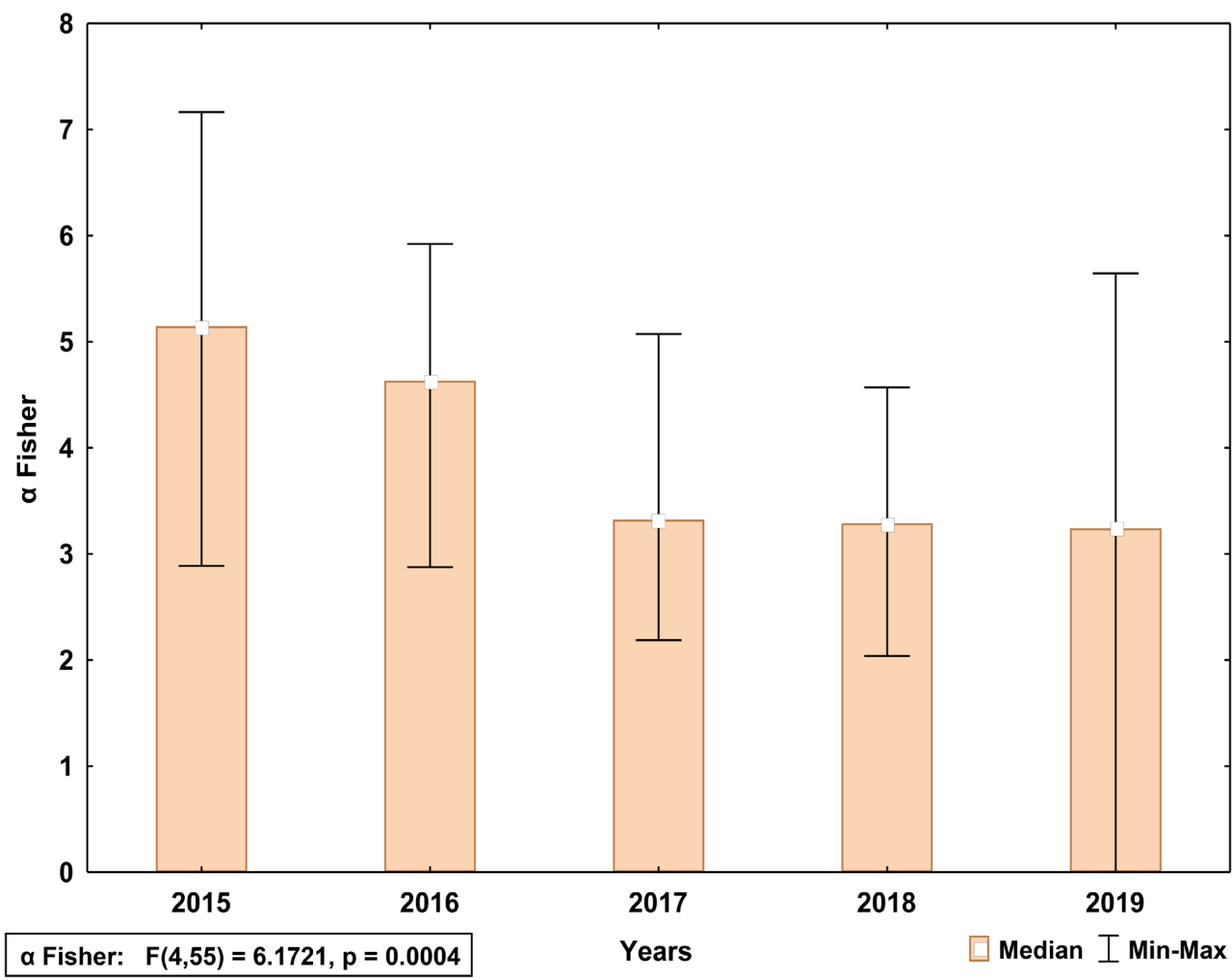

Figure 4. Annual Fisher's alpha ( $\alpha$-Fisher) values recorded in the tide pools of El Faro. Confidence interval of $95 \%$.

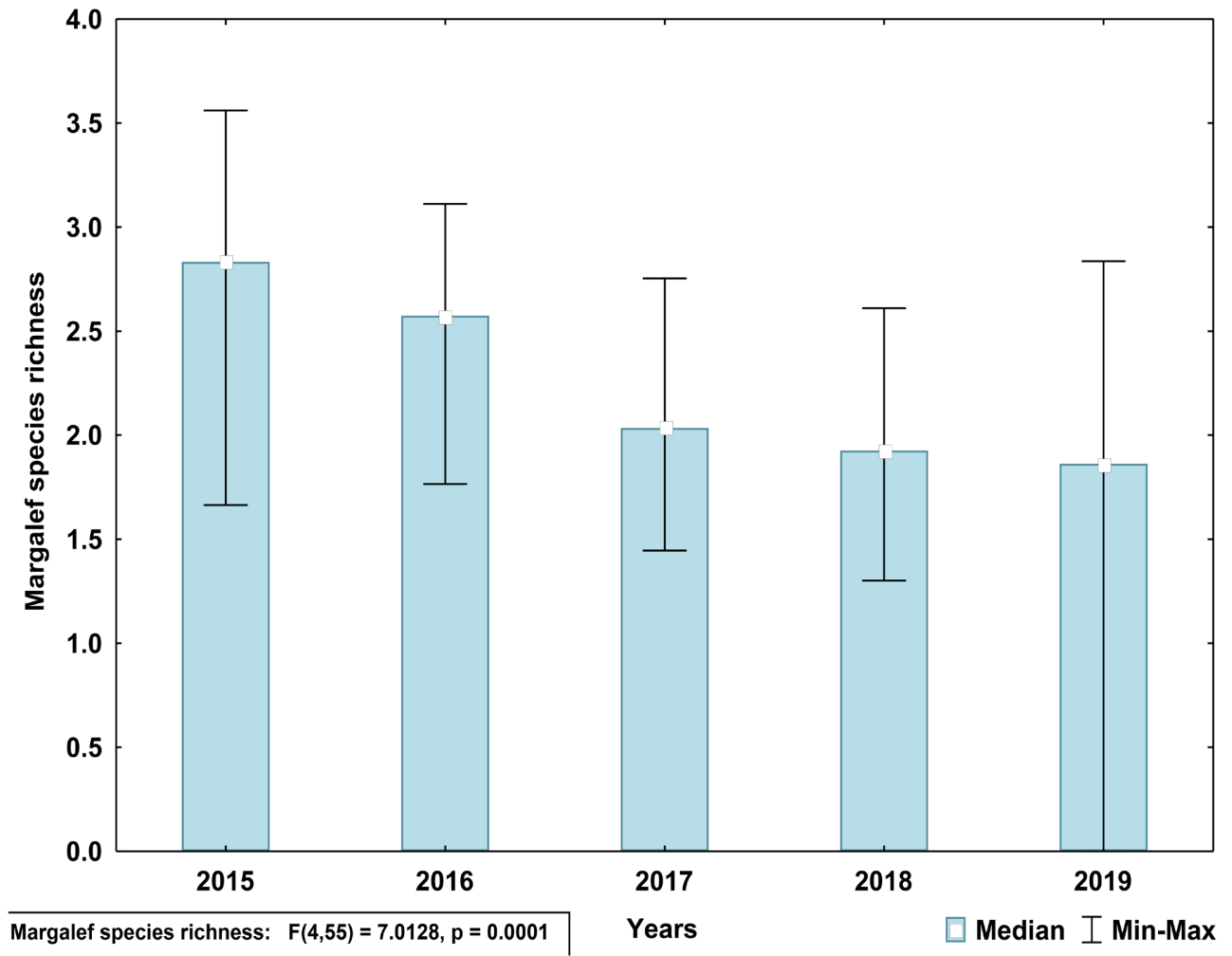

Figure 5. Annual species richness values recorded in the tide pools of El Faro. Confidence interval of $95 \%$. 


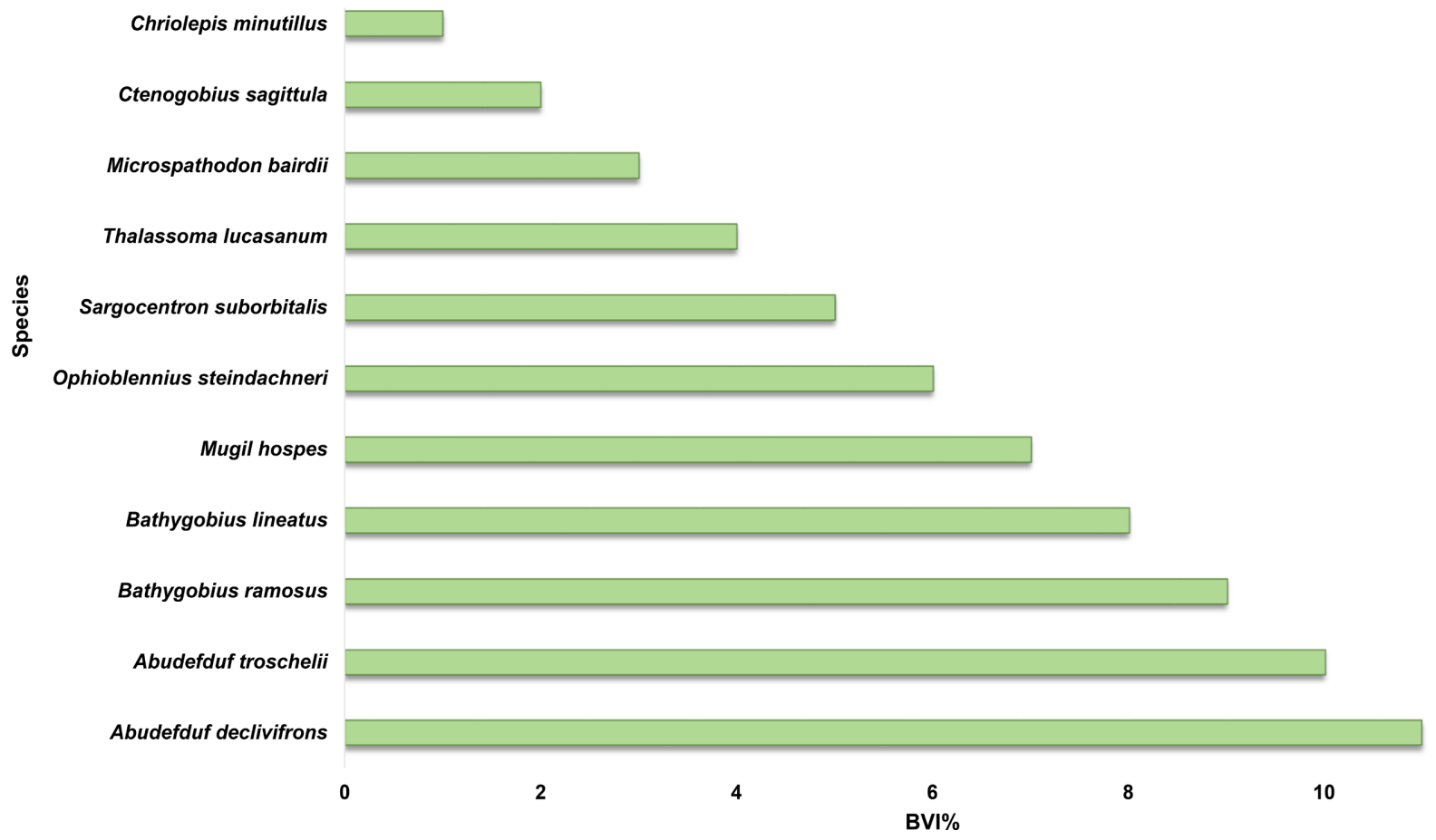

Figure 6. Biological Value Index (BVI) showing the dominance of the fish species recorded in the tide pools of El Faro.

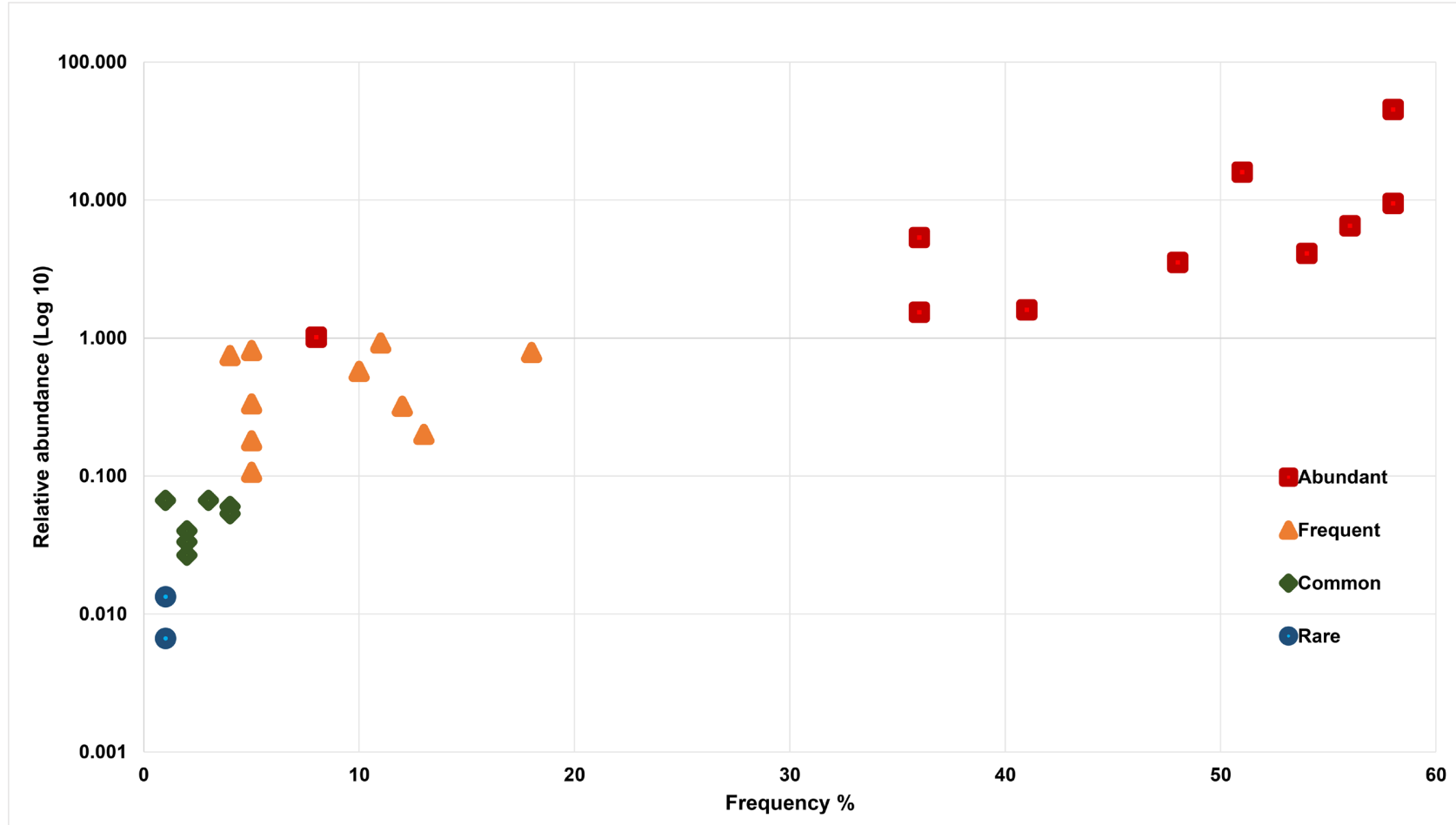

Figure 7. Classification according to relative abundance and frequency of appearance of the 30 fish species recorded in the tide pools of El Faro.

Exerpes asper, Hypsoblennius jenkinsi, Malacoctenus margaritae, Prionurus punctatus, Johnrandallia nigrirostris, Hypsoblennius brevipinnis and Microgobius brevispinis. 


\section{Common species}

Seven species were classified as common, recording a relative abundance between $0.02 \%$ to $0.09 \%$ : Chaetodon humeralis, Umbrina xanti, Stegastes flavilatus, Epinephelus labriformis, Gibbonsia montereyensis, Chromis limbaughi and Kyphosus elegans.

Rare species

Three species were classified as rare, recording a relative abundance between $0.007 \%$ to $0.01 \%$ : Diodon hystrix, Halichoeres nicholsi and Melichthys niger.

\section{Discussion}

\section{Physicochemical variables}

The intertidal zone, particularly tide pools, are areas in which environmental variables tend to drastically change throughout the day [14]. Physicochemical variables like temperature and salinity fluctuate according to the tide cycle, especially during the low tide when tide pools are exposed to air [15] [16]. In addition, direct solar radiation, wind, desiccation and rainfall can cause a drastic variation of temperature and salinity, alongside their natural variation pattern throughout the seasons [17].

In the present study, temperature showed significant differences between months $(\mathrm{p}<0.001)$ and years $(\mathrm{p}<0.001)$, with two distinct climatic seasons, warm (July to November) and cold (December to May). In addition, there were differences between temperature of the tide pools and the sea, particularly during the warm season, which can be attributable to the intense solar radiation during the summer months [16], which causes an increment of temperature and evaporation of the water trapped in the tide pools, particularly during the low tide, when there is no water replacement. This has been supported by González-Murcia [18], reporting higher temperatures during the rainy months (between July and October) in the rocky intertidal zone of Los Cobanos in El Salvador, which is located in the tropical eastern pacific, with climatic conditions similar to our study area. Other studies by Barjau et al., [19] and Barjau et al., [20] have reported similar temperatures, with September as the hottest month $\left(32.64^{\circ} \mathrm{C}\right)$, followed by $\mathrm{Au}-$ gust and October $\left(32.53^{\circ} \mathrm{C}\right.$ and $32.43^{\circ} \mathrm{C}$, respectively), and January as the coldest month $\left(24.30^{\circ} \mathrm{C}\right)$. A study by Castillo-Rosas et al., [21] in La Paz lagoon (west coast of the Gulf of California), two climatic seasons were recorded as well, with an increment of temperatures from August to October and a mean temperature of $27.45^{\circ} \mathrm{C}$, and a colder period from December to June, with a mean temperature of $22.49^{\circ} \mathrm{C}$. Likewise, Barjau-González [22] recorded similar temperatures in La Paz Bay, with February as the coldest month $\left(19.58^{\circ} \mathrm{C}\right)$, and July as the hottest month $\left(26.75^{\circ} \mathrm{C}\right)$. In addition, two climatic seasons were recorded as well, warm $\left(26.37^{\circ} \mathrm{C}\right)$ and cold $\left(21.15^{\circ} \mathrm{C}\right)$.

Regarding annual variations, although changes of temperature in consecutive years are usually relatively stable [23], according to our results, there were significant differences between years ( $p<0.001$ ), with 2015 and 2016 as the warm- 
est years. This increment of temperature could have been caused by the occurrence of El Niño Southern Oscillation (ENSO) during those years [24] [25], recorded as one of the strongest events since 1950 [26]. Franco-Campos [27] reported a mean temperature between $26.18^{\circ} \mathrm{C}-27.26^{\circ} \mathrm{C}$ in the rocky intertidal zone of Ecuador, slightly lower than the ones reported in the present study. This is probably due to the influence of the Humboldt current, which is characterized by cold water [28] [29].

Salinity showed significant differences between years $(\mathrm{p}<0.001)$. Although 2015 and 2016 were the hottest years, they showed the lowest salinity values (28.95 UPS and 30.56 UPS, respectively). Contrary to 2018 and 2019 with the highest values (35.15 UPS and 34.69 UPS, respectively). This is probably because fluctuations of salinity are not only related to water evaporation but also rainfall, continental discharge, wave action and movement of organisms [5]. In addition, because of the occurrence of El Niño Southern Oscillation (ENSO) during 2015 and 2016, there were more rainstorms, which translates to more freshwater input and cloudy days (less solar radiation), perhaps causing less evaporation and lower salinity values. In comparison, Barjau et al., [19] and Barjau et al., [20] reported significant differences of salinity between the warmer months. Contrary to our results, in which the highest values were recorded in November and December over the five years of study. González-Murcia, [18] reported salinity values ranging from 14.1 to 36.6 UPS, with January recording the lowest value and October recording the highest value, which are similar to our results perhaps due to the fact that their study area Los Cóbanos in El Salvador is located in the tropical eastern pacific, just like our study area El Faro, which is characterized by a rainy season with high temperatures and lower solar incidence, resulting in lowers salinity values, compared to other seasons [30].

Dissolved oxygen showed significant differences between months and years $(\mathrm{p}<0.001)$. These fluctuations are caused by the changes of photosynthetic activity throughout the year, alongside the differential oxygen demand by the variation in abundance of different organisms (fish, mollusks, crustacean, anemones, echinoderms, etc) throughout the year and period of study [5]. González-Murcia [18] reported similar results, with the highest values recorded in the coldest months (January to March). On the contrary, Barjau-González [31] reported significant differences between the two climatic seasons in San Jose Island (north of La Paz Bay), with low values during the cold season and high values during the warm season. Regarding the relationship between DO and other physicochemical variables like temperature, there is a negative relationship between these two variables (Table 1). As mentioned by Alvarado and Aguilar [32], dissolved oxygen solubility increases when temperature and salinity decrease because these variables affect the optimum oxygen saturation in a water body. Previous studies by Núnez et al., [33] and Martínez-Porchas et al., [34] showed that dissolved oxygen in low concentrations have a direct effect in the growth and development of organisms. Since there is not enough oxygen for the mainten- 
ance of nutrient metabolism to obtain energy for growth and development, other metabolic processes for basic sustenance take priority. In addition, De los Santos Rodríguez [35] showed that oxygen deficiency impacts the overall health of organisms by affecting the blood cells (erythrocytes), therefore causing issues with oxygen transportation, which may cause an increment of certain metabolic processes like glucogenesis, causing a drastic decrease of glycogen in the liver, as well as protein and glucose in blood, therefore causing osmoregulation problems.

\section{Relative abundance}

Relative abundance shows the most representative species in a community. In the present study, a total of 14,995 organisms were recorded, belonging to 30 species. Barjau et al., [19] reported a total of 3754 organisms belonging to 22 species for the same study area. However, their study only looked at variations in one year (2015), while the present study looks at the overall variation during five consecutive years. In addition, Abudefduf declivifrons and $A$. troschelii were the most abundant species throughout the study period, which are species with similar life histories, belonging to the same trophic level, with similar reproductive behaviors like laying their eggs on rocks and exhibit parental care by males [27] [28]. In comparison, Stepien et al., [36] reported 516 organisms belonging to 19 species in a study carried out in Punta Clara, Baja California, in which Gibbonsia elegans and Clinocottus analis were the most abundant species. These species have been recorded in cold temperate areas (Oregon) but are not usually recorded in the Californian province. The remaining species are distributed near the South of the Baja California peninsula. However, the species recorded by Stepien et al., [36] were not recorded in the present study, perhaps due to the climatic differences between study areas. Temperatures in Punta Clara are significantly lower than subtropical areas like our study site, ranging from 10 to $16^{\circ} \mathrm{C}$ throughout the year. González-Murcia et al., [18] recorded 2385 organisms belonging to 48 species in Los Cobanos, El Salvador. The most abundant species were Bathygobius ramosus, Stegastes acapulcoensis, Dormitator latifrons, Abudefduf concolor, Sargocentron suborbitalis and Epinephelus labriformis. B. ramosus and $S$. suborbitalis were recorded in the present study as well, as two of the most abundant species, and the other species share similar characteristics like belonging to the same trophic levels or families. This is probably because Los Cobanos and our study area El Faro, have similar climatological conditions such as semiarid climate with low humidity, prolonged periods of drought and rainfall shortage throughout the year [37]. Moreover, other studies carried out in the intertidal zone in Chile [38] [39], have recorded species belonging to the same families as those recorded in the present study, like those recorded in the Californian province, with a distribution in the temperate-warm zone. Furthermore, Sindorf et al., [40] reported 235 organisms belonging to 55 species in a marine park of the western indian ocean in Kenya. Gobiidae was the most common family, followed by Blenniidae and Pomacentridae. These families were also recorded in the present study, which shows that both study areas have simi- 
lar climatological conditions, recording a minimum temperature of $25^{\circ} \mathrm{C}$.

\section{Species richness}

Species richness showed significant differences between years, with 2015 and 2016 recording the highest values alongside the highest temperatures (above $28^{\circ} \mathrm{C}$ ) (Table 1, Figure 3). On the contrary, 2019 showed the lowest value of species richness and lowest temperature. Based on this, species recorded in the tide pools exhibit preference to subtropical and warmer conditions [21]. In addition, this is consistent to that reported by González-Murcia [18], about the relationship between abundance and species richness in the tide pools that exhibit higher algal coverage in the substrate. Environmental variables like temperature and salinity, as well as type of substrate and algae coverage, and their fluctuation through time have a direct impact on the number of species in a community, which depends on the way species respond to environmental change [18] [21] [41]. Moreover, Barjau et al., [19] reported significant differences between months ( $\mathrm{p}<0.05$ ), with April and July showing the highest values (3.56 and 3.53, respectively), while the lowest values were recorded in December and February (1.66 and 2.20, respectively), showing an increase of diversity perhaps related to the preference of species to warmer conditions. Aldana-Moreno [42] carried out a study in the Gulf of California and reported that species richness showed a latitudinal gradient from north to south.

Other studies by González-Murcia et al., [18] and Sindorf et al., [40], did not find significant differences of species richness in tide pools, but mentioned that changes of species richness were related to water volume. Contrary to our results, Franco-Campos [27] reported an increase of species richness during the cold season, probably due to the difference of fish community structure between the two study areas. Therefore, our results suggest that species exhibit a higher affinity for warmer conditions, recording higher values of species richness in the summer. Castillo-Rosas et al., [21] reported similar results in La Paz lagoon, with lower values of species richness during autumn and winter (from October to February), and an increase during the warmer months in spring and summer (from April to August). Consistent to results reported by Barjau-González [43] in San Ignacio lagoon, where species richness increased during the warmer months, and decreased during the colder months.

\section{Diversity}

Two indices were used to determine diversity of the fish assemblages of tide pools. Fisher's alpha calculates diversity according to number of organisms and number of species without considering sample size, and Shannon-Wiener's index, which according to Krebs [44], may present some difficulties during data analysis, like deviation from normality related to sample size, as well as difficulties of its ecological interpretation given the units it uses.

Fisher's alpha showed significant differences between years $(\mathrm{p}<0.001)$, with 2015 and 2016 as the most diverse years (Table 1). As previously mentioned, 2015 and 2016 were the warmest years, probably attracting more species with affinity to warmer conditions, with the presence of both tropical and subtropical 
species. Barjau et al., [19] reported higher values of the Shannon-Wiener's index (3.20 bits/ind.) for 2015, with significant differences between months. Likewise, Sindorf et al., [40] reported similar values of diversity (3.15 bits/ind.). Our results of this index show lower diversity values ( 0.86 bits/ind.) with no significant differences between months ( $\mathrm{p}=0.6447)$, perhaps related to difference between sample sizes and duration of study period. In comparison, Fisher's alpha calculates diversity more efficiently since it considers number of organisms and number of species.

Condit et al., [45] reported values of $S=3.94$, similar values to those reported by Barjau et al., [19] with a mean diversity of $S=5.15$, with April showing the highest diversity value, while December showed the lowest value. According to Laroche et al., [46] [47], diversity and abundance of species tend to gradually decrease from autumn to winter as a result of environmental factors like decrease salinity and rainfall, in addition to other factors like seasonal and circadian cycles like trophic and reproductive behavior as well as migration [48]. This is consistent with our results, in which the higher values of diversity were recorded during the warmer months (spring/summer) and the lowest values were recorded in the colder months (autumn and winter).

Regarding the classification of species according to their relative abundance and frequency of appearance, 10 species were classified as abundant, with $A$. declivifrons and $A$. troschelii (Figure 6) showing the higher values of BVI (11 and $10 \%$ respectively). Species from the genus Abudefdeuf are widely distributed in the eastern pacific. They are usually found in small groups, and as a result their abundance in the tide pools is usually high when they become trapped during the low tide. $A$. declivifrons is the most abundant species, with a strong preference for rocky areas because of its feeding preferences (algae and small sessile animals). A. troschelii is an omnivorous species that also prefers rocky areas where it feeds on zooplankton [49] [50]. All abundant species in this study share feeding and breeding habits, as well as the ability to tolerate drastic environmental changes, which allows them to inhabit the rocky intertidal zone, but also have a direct influence on their abundances and frequency of appearance during different seasons throughout the year [51] [52].

\section{Conclusion}

Physicochemical variables showed significant temporal fluctuations, which showed a relationship with the fish community structure of the tide pools. Ecological indices did not show significant differences between months. However, April recorded the highest species richness and diversity, which can be a consequence of favorable environmental conditions during the season. In addition, there were significant differences between years, with 2015 and 2016 as the most diverse years of the study period, while 2019 showed the lowest species richness and diversity, perhaps due to the influence of harsh environmental conditions, particularly during the second semester. Furthermore, the dominance of certain species through- 
out the years, shows that these species are important for the structure and dynamic of the tide pool communities of El Faro, Baja California Sur.

\section{Authors' Contributions}

LECO analyzed data and wrote the manuscript. EBG designed and carried out visual censuses, including counting and identification of the fish species. JAAQ georeferenced the sampling site. EBG, JMLV, JAAQ, JAP and EEAF revised the manuscript. All authors read and approved the final manuscript. Likewise, all authors declare no conflict of interest.

\section{Acknowledgments}

Authors would like to thank MSc. Myrna Barjau Pérez Milicua for the English translation and editing of the manuscript.

\section{Conflicts of Interest}

The author declares no conflicts of interest regarding the publication of this paper.

\section{References}

[1] Wilkinson, T., Wiken, E., Bezaury Creel, J., Hourigan, T., Agardy, T., Herrmann, H., Janishevski, L., Madden, C., Morgan, L. and Padilla, M. (2009) Ecorregiones marinas de América del Norte, Comisión para la Cooperación Ambiental. CEC. Canadá, 197.

[2] Espinosa-Leal, L. (2014) Variación estacional de los anfípodos hipéridos en la zona frente a Punta Eugenia-Punta Abreojos, Baja California durante un año frío. México. Tesis Maestría. CICESE.

[3] Villegas-Sánchez, C., Abitia-Cárdenas, L., Gutiérrez-Sánchez, F. and Galván-Magaña, F. (2009) Rocky Reef Fish Assemblages at San José Island, Mexico. Revista Mexicana de Biodiversidad, 80, 169-179. https://doi.org/10.22201/ib.20078706e.2009.001.594

[4] Sánchez, O.A. (2007) Perspectivas sobre conservación de ecosistemas acuáticos en México. Escuela de biología de la universidad michoacana. México. 15-18.

[5] Fueyo-Sanchez, L. (2008) Redes tróficas y flujos de energía en comunidades de pozas de mareas del mar de plata. Argentina. Universidad nacional de Luján. 15-55.

[6] Meek, S.E. and Hildebrand, S.F. (1923) The Marine Fishes of Panama. Field Museum of Natural History (Zoology), 15(1-4).

[7] Zahuranec, B.V. (1967) The Gerreid Fishes of the Genus Eucinostomus in the Eastern Pacific. Master's Thesis, Scripps Institution of Oceanography, University of California, Berkeley, 212.

[8] Miller, D.J. and Lea, R.N. (1976) Guide to the Coastal Marine Fishes of California, State of California, Department of Fish and Game. California Fish Bulletin 157, (32): $1-249$.

[9] Whitehead, P.J.P. (1985) FAO Species Catalogue, Clupeid of the World, an Annotated and Illustrated Catalogue of the Herrings, Sardines, Pilchards, Sprats, Shads, Anchovies and Wolf-Herrings. EUA: Fisheries Synopsis. 1-303.

[10] Whitehead, P.J.P., Bauchot, M.L., Jureau, J.C., Nielsen, J. and Tortonese, E. (1986) Fishes of the North-Eastern Atlantic and the Mediterranean. UNESCO, Francia, 
1473-1495. https://doi.org/10.2307/1444931

[11] Fischer, W., Krupp, F., Schneider, W., Sommer, C., Carpenter, K.E. and Niem, V.H. (1995) Guía.

[12] Allen, G.R. and Ross-Robertson, D.R. (1998) Peces del Pacífico Oriental Tropical. Crawford House Press Pty Ltd., México. CONABIO y Agrupación Sierra Madre, S.C. 327.

[13] Granado, C. (2007) Avances en ecología: Hacia un mejor conocimiento de la naturaleza. Universidad de Sevilla, España, 90-100.

[14] Fernández, E. (2008) Sistemas silvopastorales establecidos con Pinus radiata, D. Don y Betula alba, en Galicia: Productividad y biodiversidad. Tesis doctoral. USC.

[15] Briggs, J.C. (1974) Marine Zoogeography. McGraw-Hill Book Company, New York, 475.

[16] Little, C. and KitChing, J.A. (1996) The Biology of Rocky Shores. Oxford University Press, Oxford, 252.

[17] Veiga, M. (2008) La meiofauna intermareal de sustratos blandos de la ría do Barqueiro. USC, Chile, 220-225.

[18] González-Murcia, S. (2011) Diversidad, estructura y distribución de la comunidad de peces en la zona intermareal rocosa del área natural protegida Los Cóbanos, Acajutla, departamento de sonsonate, El Salvador. Tesis Licenciatura. Universidad de El Salvador.

[19] Barjau, E., Romo-Piñeda, A.K., López-Vivas, J.M., Pérez-Castillo, J. and Milicua, M.B.P. (2017) Variation of the Structure of the Intertidal Fish Community of the Pacific Coast of Baja California Sur, México. International Journal of Marine Science, 7 , 455-464.

[20] Barjau, E., Armenta-Quintana, J.A., López-Viva, J.M. and Romero-Vadillo, E. (2019) Taxonomic Distinctness of the Intertidal Fish Community on the Pacific Coast of Baja California Sur, México. Open Journal of Marine Science, 9, 86-97. https://doi.org/10.4236/ojms.2019.92007

[21] Castillo-Rosas, B.R., Barjau-González, E., López-Vivas, J.M., Romo-Piñeda, A.K., Romero-Vadillo, E. and Armenta-Quintana, J.Á. (2020) Structure of the Community of Dominant Fish Species Associated to Soft-Bottoms in the Lagoon of La Paz, BCS, México. Open Journal of Marine Science, 10, 79-92.

https://doi.org/10.4236/ojms.2020.103006

[22] Barjau, E. (2012) Estructura comunitaria y diversidad taxonómica de los peces de la bahía de La Paz y la isla San José, Golfo de California. Tesis doctoral, Centro de Investigaciones Biológicas del Noroeste. http://dspace.cibnor.mx:8080/handle/123456789/321

[23] Villalobos, R., Retana, J.A. and Acuña, A. (2000) El Niño y los incendios forestales en Costa Rica. Tópicos Meteorológicosy Oceanográficos, 7, 1-20.

[24] Brainard, R.E., Oliver, T., McPhaden, M.J., Cohen, A., Venegas, R., Heenan, A. and Hunter, S.A. (2018) Ecological Impacts of the 2015/16 El Niño in the Central Equatorial Pacific. Bulletin of the American Meteorological Society, 99, S21-S26. https://doi.org/10.1175/BAMS-D-17-0128.1

[25] Liberto, T. (2016, de agoosto de 25) Going Out for Ice Cream: A First Date with the Pacific Decadal Oscillation. Climate.gov.

https://www.climate.gov/news-features/blogs/enso/going-out-ice-cream-first-date-p acific-decadal-oscillation

[26] Martínez, R., Zambrano, E., Nieto, J.J., Hernández, J. and Costa, F. (2017) Evolución, vulnerabilidad e impactos económicos y sociales de El Niño 2015-2016 en América 
Latina. Investigaciones Geográficas, 68, 65-78. https://doi.org/10.14198/INGEO2017.68.04

[27] Franco Campos, A.D. (2012) Caracterización ecológica de las comunidades intermareales rocosas a lo largo de una gradiente de productividad en las costas del Ecuador. Tesis de licenciatura. Universidad Catolica de Ecuador, Ecuador, 75.

[28] Alheit, J. and Niquen, M. (2004) Regime Shifts in the Humboldt Current Ecosystem. Progress in Oceanography, 60, 201-222. https://doi.org/10.1016/j.pocean.2004.02.006

[29] Firstater, F., Hidalgo, F., Lomovasky, B., Ramos, E., Gamero, P. and Iribarne, O. (2011) Habitat Structure Is More Important than Nutrient Supply in Modifying Mussel Bed Assemblage in an Upwelling Area of the Peruvian Coast. Helgoland Marine Research, 65, 187-196. https://doi.org/10.1007/s10152-010-0214-3

[30] DCroz, L.D. and Roberson, D. (1997) Coastal Oceanographic Conditions Affecting Coral Reefs on Both Sides of the Isthmus of Panamá. Proceedings of the 8 th International Coral Reefs Symposium, Vol. 2, 2053-2058.

[31] Barjau, E., Rodríguez-Romero, J., Galván, F., Gutiérrez, F. and López, J. (2012) Estructura temporal y espacial de la comunidad de peces arrecifales de la Isla San José, Golfo de California, México. Revista de Biología Tropical, 60, 649-667. https://doi.org/10.15517/rbt.v60i2.3957

[32] Alvarado, J. and Aguilar, J. (2009) Batimetría, salinidad, temperatura y oxígeno disuelto en aguas del Parque Nacional Marino Ballena, Pacífico, Costa Rica. Revista de Biología Tropical, 57, 19-29.

[33] Núñez, H., Vargas, R., Guerra, I. and Ramos, E. (2021) Efecto de la temperatura sobre el consumo de oxígeno en tilapias del Nilo con diferentes fenotipos de comportamiento. Centros. Revista Científica Universitaria, 10, 1-18.

[34] Martínez-Porchas, M., Martínez-Córdova, L.R. and Ramos-Enríquez, R. (2009) Dinámica de crecimiento de peces y crustáceos. Redvet. Revista electrónica de Veterinaria, 10, 1-16.

[35] De los Santos Rodríguez, E. (2017) Respuesta fisiológicas de peces sometidos a estrés. Tesis de licenciatura, Universidad de la Laguna, Laguna, 33.

[36] Stepien, C.A., Phillips, H., Adler, J.A. and Mangold, P.J. (1991) Biogeographic Relationships of a Rocky Intertidal Fish Assemblage in an Area of Cold Water Upwelling off Baja California, Mexico. Pacific Science, 45, 63-71.

[37] Jiménez, T. (2007) Tendencias del clima en El Salvador. Minerva Revista en Línea CIC-UES, 1-11.

[38] Fisher, R., Sclater, J. and Mckenzie, D. (1971) Evolution of the Central Indian Ridge, Western Indian Ocean. Geological Society of America Bulletin, 82, 553-562. https://doi.org/10.1130/0016-7606(1971)82[553:EOTCIR]2.0.CO;2

[39] Stepien, C.A. (1990) Population Structure, Diets and Biogeographic Relationships of a Rocky Intertidal Fish Assemblage in Central Chile: High Levels of Herbivory in a Temperate System. Bulletin of Marine Science, 47, 598-612.

[40] Sindorf, V., Cowburn, B. and Sluka, R.D. (2015) Rocky Intertidal Fish Assemblage of the Watamu Marine National Park, Kenya (Western Indian Ocean). Environmental Biology of Fishes, 98, 1777-1785. https://doi.org/10.1007/s10641-015-0397-1

[41] White, G.E., Hose, G.C. and Brown, C. (2015) Influence of Rock-Pool Characteristics on the Distribution and Abundance of Intertidal Fishes. Marine Ecology, 36, 1332-1344. https://doi.org/10.1111/maec.12232

[42] Aldana-Moreno, A. (2012) Variación espacial de la estructura comunitaria de peces 
de arrecife de la costa oeste del Golfo de California. Tesis Doctoral, Centro de investigaciones biologicas del noroeste.

[43] Barjau-González, E. (2003) Estructura de la ictiofauna asociada a fondos blandos en Laguna San Ignacio, Baja California Sur, México. M.S. Tesis de maestria, CICIMAR-IPN, México.

[44] Krebs, C.J. (2006) Ecology: The Experimental Analysis of Distribution and Abundance. 6th Edition, Benjamin Cummings Publisher, Benjamin, 453.

[45] Condit, R., Hubbell, S.P. and Foster, R.B. (1996) Changes in Tree Species Abundance in a Neotropical Forest: Impact of Climate Change. Journal of Tropical Ecology, 12, 231. https://doi.org/10.1017/S0266467400009433

[46] Laroche, J., Baran, E. and Rasoanandrasana, N.B. (1997) Temporal Patterns in a Fish Assemblage of a Semiarid Mangrove Zone in Madagascar. Journal of Fish Biology, 51, 3-20. https://doi.org/10.1111/j.1095-8649.1997.tb02509.x

[47] Leal De Castro, A.E. (2001) Diversidade de assebléia de peixes emlgarapés do estuario do Rio Paciencia (Ma-Brasil). Atlântica, Rio Grande, 23, 39-46.

[48] Trenkel, V.M. and Rochet, M.J. (2003) Performance of Indicators Derived from Abundance Estimates for Detecting the Impact of Fishing on a Fish Community. Canadian Journal of Fisheries and Aquatic Sciences, 60, 67-85. https://doi.org/10.1139/f02-163

[49] Jiménez, S.A. (1999) Abundancia y estructura comunitaria de peces de arrecife rocoso en la zona de isla Cerralvo, B.C.S, México. Tesis de Maestría, Centro de investigaciones biológicas del noroeste. http://repositoriodigital.ipn.mx/handle/123456789/14843

[50] Aguilar Medrano, R. (2012) Ecomorfología y evolución de la familia pomacentridae (Labroidei: Perciformes) en el Pacífico oriental. Tesis Doctoral, Centro de investigaciones biológicas del noroeste.

[51] Acevedo-Cervantes, A. (1997) Caracterización ecológica de la comunidad íctica de la Laguna Ojo de Liebre, B.C.S. México. Tesis Maestría, Centro Interdisciplinario de Ciencias Marinas. Instituto Politécnico Nacional, 107.

[52] Balart, E.F., Castro-Aguirre, J.L. and De Lachica-Bonilla, F. (1997) Análisis comparativo de las comunidades ícticas de fondos blandos y someros de la Bahía de La Paz, BCS. La Bahía de La Paz investigación y conservación, Universidad Autónoma de Baja California Sur, 177-188. 